\title{
Actinorhizal plants in rangelands of the western United States
}

\author{
MARK W. PASCHKE
}

Abstract

Actinorhizal plants are a diverse group of trees and shrubs that have the ability to form a dinitrogen-fixing symbiosis with Frankia bacteria. Actinorhizal plants are found throughout the world and are a significant component of rangelands in the western United States. Many actinorhizal species play important ecological roles in the habitats where they occur. Actinorhizal shrubs such as bitterbrush (Purshia tridentata [Pursh DC.]), mountain mahogany (Cercocarpus spp), and Ceanothus spp. are among the most important wildlife browse species in the western U.S. Other actinorhizal taxa such as alders (Alnus) and dryads (Dryas) play important roles in soil development and community succession following disturbance. Despite their importance, the biology of these plants in rangeland ecosystems is poorly understood. Particularly lacking is understanding of the dinitrogen-fixing ability of these plants and how symbioses with Frankia bacteria affects the ecology of these plants in western U.S. rangelands. Difficulty in isolating and culturing Frankia bacteria and in measuring inputs of fixed $\mathbf{N}$ from actinorhizal plants has contributed to slow progress in this field. In spite of these shortcomings, the actinorhizal plants of western U.S. rangelands represent a valuable resource for expanded utilization. This review is a summary of current knowledge of actinorhizal range plants and their Frankia symbionts. It is intended to provide a scientific basis for the study and utilization of this symbiosis for those involved in rangeland research and management.

Key Words: Frankia, symbiosis, reclamation, dinitrogen fixation, browse.

Actinorhizal plants are a group of taxonomically diverse species capable of forming a symbiosis with $\mathrm{N}_{2}$-fixing soil actinomycetes of the genus Frankia. The term "actinorhizal" is formed from the roots "actino" for the Frankia actinomycete and "rhiza" for the plant roots bearing the symbiosis (Baker and Schwintzer 1990). This symbiosis should not be confused with the more well-known symbioses between plants and non- $\mathrm{N}_{2}$-fixing mycorrhizal fungi or between legumes and $\mathrm{N}_{2}$-fixing Rhizobia bacteria. Frankia are filamentous, branching, and primarily saprophytic bacteria of the order Actinomycete. Frankia can live both symbiotically in root nodules and saprophytically in soil. Plants from 8 families and 25 genera are known to form a symbiosis with Frankia (Benson 1988, Dawson 1992). All acti-

The author is grateful to J.O. Dawson, E.F. Redente, W.M. Childress, T. McLendon, C.E. Richard, and J.L. Paschke for constructive comments on preliminary drafts of this manuscript.

Manuscript accepted 21 February 1996
Resúmen

Las plantas actinorizoides son un grupo diverso de arboles y arbustos que poseen la habilidad de formar una simbiosis fijadora de nitrógeno con bacterias del genero Frankia. Las plantas actinorizoides se encuentran por todo el mundo y comprenden un componente significativo de los pastizales del Oeste de los Estados Unidos. Muchas especies actinorizoides juegan un papel ecológico importante en los habitats en donde se encuentran. Los arbustos actinorizoides como Purshia tridentata, Cercocarpus spp. y Ceanothus spp., se encuentran entre las especies mas importantes para ramoneo por la fauna silvestre en el Oeste de los Estados Unidos. Otras especies actinorizoides, tales como Alnus y Dryas, juegan papeles importantes en el desarrollo del suelo y en la sucesión después de un disturbio. A pesar de su importancia, la biologia de estas plantas en los ecosistemas de pastizales naturales en poco comprendida, desconociéndose la habilidad que tienen estas plantas de fijar nitrógeno y como las simbiosis con bacterias del genero Frankia, afectan la ecologia de estas plantas en los pastizales del Oeste de los Estados Unidos. La dificultad en aislar y cultivar la bacteria Frankia y en medir los flujos del nitrógeno fijado por medio de las plantas actinoriziodes, ha contribuido al lento progreso en este campo de estudio. A pesar de estas carencias, las plantas actinorizoides de los pastizales de los Estados Unidos representan un valioso recurso. Esta revisión es un resumen del actual conocimiento sobre las plantas actinorizoides de los pastizales y sus simbiontes. Esta revisión tiene como intención el proveer una base cientifica para el estudio y utilización de estas simbiosis y el manejo de pastizales con dichas especies.

norhizal plants are woody, with the exception of 2 subshrubs in the genus Datisca that have herbaceous shoots arising from woody perennial rootstocks. There are over 100 actinorhizal species native to the United States, and several introduced species are now widely naturalized and regarded as noxious weeds (e.g. Russian-olive [Elaeagnus angustifolia L.], autumn-olive [Elaeagnus umbellata Thunb.], Australian pine or she-oak [Casuarina equisetifolia Forst. \& Forst.]). Most actinorhizal species are capable of growing in $\mathrm{N}$-free culture and of fixing ecologically significant amounts of $\mathrm{N}$ in perennial woody root nodules (Fig. 1). This ability allows them to tlourish in soils where low levels of available $\mathrm{N}$ may preclude the growth of other species.

Actinorhizal plants are found throughout the world from the tropics to the arctic. The vast majority of actinorhizal species, however, are native to temperate regions, where they fill the eco- 


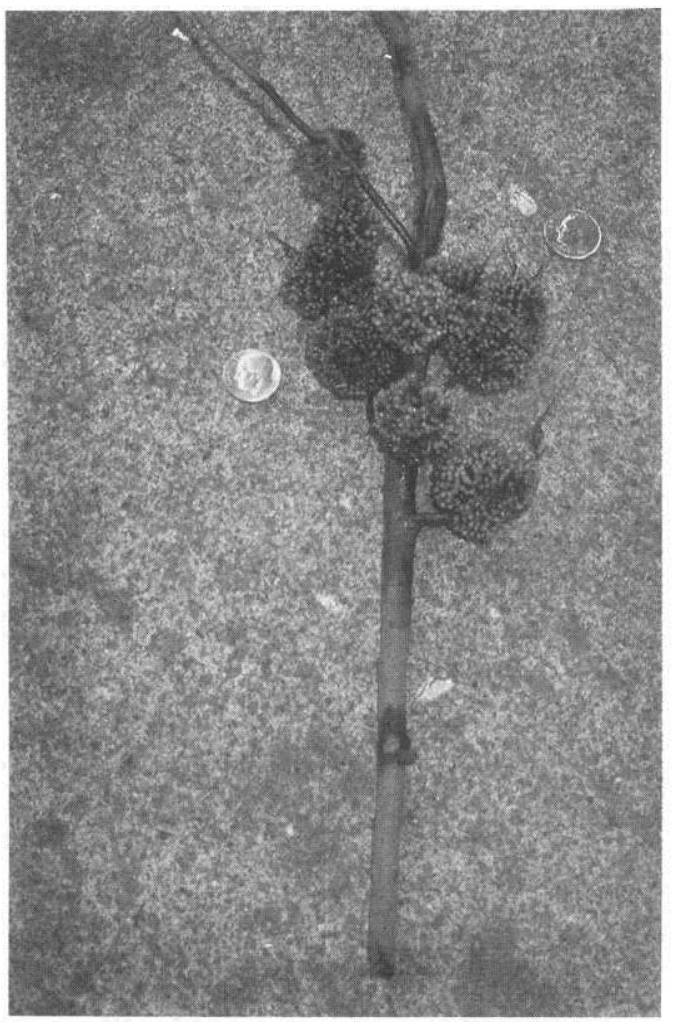

Fig. 1. A root segment from an actinorhizal Alnus rubra Bong. tree showing numerous perennial, woody root nodules that contain $\mathbf{N}_{2}$ fixing Frankia bacteria. The coins in the photo are approximately $18 \mathrm{~mm}$ in diameter.

logical role occupied by woody legumes in tropical and subtropi$\mathrm{cal}$ regions. There are approximately 80 actinorhizal plant species native to western U.S. rangelands. These species represent approximately one third of the World's known actinorhizal plants, and 6 of the 8 known actinorhizal plant families (Table 1). The western U.S. is a center of diversity for actinorhizal plant genera in the family Rosaceae, and the genus Ceanothus (family Rhamnaceae) which is composed of over 40 species. Actinorhizal plants in the western U.S. are ecologically diverse, occurring in alpine, tundra, forest, shrubland, grassland, desert, and riparian habitats.

Common actinorhizal species of western rangelands include bitterbrush (Purshia tridentata [Pursh] DC.), mountain mahogany (Cercocarpus spp.) (Fig. 2), cliffrose (Cowania mexicana [Torr.]), alders (Alnus spp.) (Fig. 2), buffaloberry (Shepherdia spp.) (Fig. 2), silverberry (Elaeagnus commutata Berbh.), Russian-olive (Elaeagnus angustifolia), and numerous species of Ceanothus (Ceanothus spp.) (Fig. 2). A single species in the genus Rubus (family Rosaceae) has been reported to be actinorhizal (Becking 1979), however, this observation has never been confirmed despite numerous surveys by several research teams (J.O. Dawson personal communication) Rubus is, thus, not currently accepted as an actinorhizal genera (Stowers 1985). The genus Dryas (family Rosaceae) is considered to be actinorhizal but it is interesting to note that alpine populations in the lower 48 states, and central and southern Europe, have never been reported to be nodulated. Most actinorhizal plants in the western U.S. are woody shrubs, therefore, they are most often found in mountain and desert shrublands, chaparral, or open-canopy forests Bitterbrush and mountain mahogany in the western U.S. form some of the most extensive stands of actinorhizal plants in the world, with bitterbrush alone occupying some $\mathbf{1 3 6}$ million ha in 11 states (Hormay 1943, Findley 1994).

There is little published research on actinorhizal rangeland shrub species despite the ecological importance of the actinorhizal symbiosis in the western U.S. (reviewed by Klemmedson 1979). The purpose of this review is to summarize the current state of knowledge regarding actinorhizal shrubs and their Frankia symbionts. It is intended to provide a scientific basis for the utilization and study of this symbiosis for those involved in rangeland research and management. For a more complete introduction to the biology of Frankia and actinorhizal plants, readers are referred to Schwintzer and Tjepkema (1990).

\section{Ecological Importance of Actinorhizal Plants}

Actinorhizal plants and their Frankia symbionts play an important role in the successional development of plant communities (Crocker and Major 1955, Lawrence et al. 1967, Conrad et al. 1985, Hibbs and Cromack 1990, Thilenius 1990). The ability to fix atmospheric $\mathrm{N}_{2}$ allows actinorhizal plants to colonize sites where lack of available soil $\mathrm{N}$ may limit establishment and growth of other plants. Once established on a site, actinorhizal plants can fix $\mathrm{N}_{2}$ and add $\mathrm{N}$ to the soil in the form of leaf litter and dead root tissue. Actinorhizal plants, therefore, build up soil organic matter and create a more favorable habitat for other plants (Crocker and Major 1955, Lawrence et al. 1967, Olff et al. 1993, Chapin et al. 1994) and soil organisms (Aplet 1990). Examples of important early successional actinorhizal plants in the western U.S. include sweetgale (Myrica gale L.) and sitka alder (Alnus viridis sinuata Regel.) in coastal wetlands of Alaska (Thilenius 1990), numerous species of Ceanothus in chaparral, forest, and mountain shrublands (Hickey and Leege 1970, Leege 1979, Conrad et al. 1985), the genus Alnus in the Pacific Northwest (Hibbs and Cromack 1990), and species of Dryas in arctic and alpine habitats in Alaska (Crocker and Major 1955, Lawrence et al. 1967). Alders and dryads were common colonizers of glacial till following the retreat of continental glaciation in the northern hemisphere (Ritchie 1987).

Other actinorhizal genera such as Purshia, Shepherdia, and Ceanothus, that are usually early successional shrubs, can occasionally persist as mid or later seral components of shrublands or open-canopied forests (Conrad et al. 1985, Dawson 1990). The ecological significance of the actinorhizal symbiosis in later seral communities is not as well-documented as in primary seres and is a topic deserving further study.

Most actinorhizal plants also possess a symbiotic relationship with mycorrhizae (Williams 1979, Rose and Youngberg 1981, Ba et al. 1987, Berliner and Torrey 1989). There is evidence that bitterbrush, mountain mahogany, and Australian she-oak (Casuarina equisetifolia L.), have the ability to simultaneously form a 3-way association with Frankia, vesicular-arbuscular mycorrhizae, and ectomycorrhizae (Williams 1979, Ba et al. 1987). The presence of mycorrhizae can lead to increased nodulation by Frankia (Fraga-Beddiar and Le Tacon 1990), and an increased phosphorus uptake from the mycorrhizal association may result in higher rates of $\mathrm{N}_{2}$-fixation relative to non-mycorrhizal plants (Rose and Youngberg 1981). The presence of mycorrhizal associations may also facilitate direct transfer of $\mathrm{N}$ from 
Table 1. Actinorhizal plant taxa of rangelands in the western United States (number of subspecies).

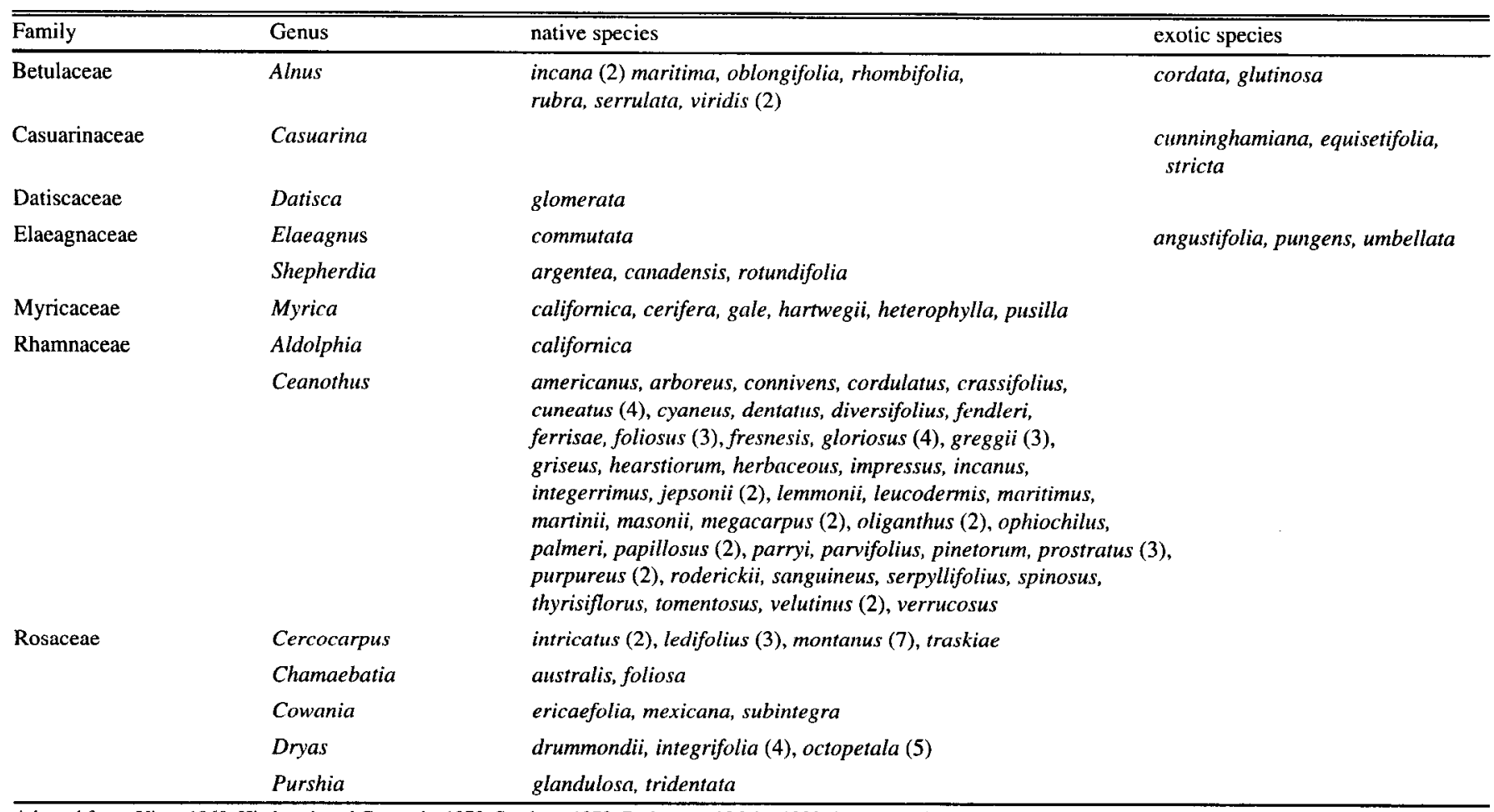

Adapted from: Vines 1960, Hitchcock and Cronquist 1973, Stephens 1973, Barbour and Major 1988, Dawson 1992, and USDA 1995.

actinorhizal to associated plant species via shared fungal mycelia (Arnebrant et al. 1993).

The amount of fixed- $\mathrm{N}_{2}$ added to ecosystems by actinorhizal plants varies considerably (Table 2). Rates of $\mathrm{N}$ accretion for slow-growing actinorhizal shrubs in the arid rangelands of the western U.S. do not approach those measured for alders (Alnus spp.) and snowbrush (Ceanothus velutinus Dougl.) in the more mesic forests of the Pacific Northwest (Table 2). Huwever, this does not mean that the seemingly low rates of $\mathrm{N}$ accretion observed for plants such as bitterbrush and mountain mahogany are not ecologically significant. The actual percentage of the total ecosystem $\mathrm{N}$ pool resulting from $\mathrm{N}_{2}$-fixation by actinorhizal plants may be similar in mesic and arid systems.

Nitrogen content in the litter of some actinorhizal plants is elevated due to a lack of $\mathrm{N}$ retranslocation from senescing leaves. Most deciduous plants will typically translocate one half or more of their foliar $\mathrm{N}$ prior to leaf abscission (Chapin and Kedrowski 1983, Côté and Dawson 1986). Several actinorhizal taxa, that have been examined, translocate a much smaller fraction (11 to $24 \%$ ) of their foliar N prior to abscission (Dawson and Funk 1981, Côté and Dawson 1986, Llinares et al. 1992, Killingbeck 1993).

There is relatively little direct information regarding the production and release of fixed $\mathrm{N}$ by actinorhizal shrubs in western U.S. rangelands. Tiedemann and Furniss (1985) found a 6-fold increase in soil total $\mathrm{N}$ beneath canopies of curl-leaf mountain mahogany (Cercocarpus ledifolius Nutt.) relative to intershrub areas, compared to a 3 -fold increase over intershrub areas for non-actinorhizal shrubs. Lepper and Fleschner (1977) found 4 times as much $\mathrm{N}$ under mixed stands of limber pine (Pinus flexilis James) and mountain mahogany than under adjacent limber pine stands lacking the actinorhizal shrub.

The lack of information regarding $\mathrm{N}$ inputs to western U.S. rangelands by actinorhizal plants can be attributed to the difficulty of making such measures. Typical methods for measuring $\mathrm{N}$ production and release from actinorhizal plants include acetylene

Table 2. Some estimates of nitrogen accretion by various actinorhizal plants.

\begin{tabular}{|c|c|c|c|c|c|}
\hline Species & Location & Habitat & & Methods & Reference \\
\hline \multicolumn{6}{|c|}{$\left(\mathrm{kg} \mathrm{N} \mathrm{ha}^{-1} \mathrm{yr}^{-1}\right)$} \\
\hline Alnus rubra & numerous & Pure stands & $100-200$ & various & Binkley et al. 1994 \\
\hline A. rubra & numerous & Mixed forest stands & $50-100$ & various & Binkley et al. 1994 \\
\hline Shepherdia canadensis & British Columbia & Clearcut & 1 & acetylene reduction & Hendrickson and Burgess 1989 \\
\hline Ceanothus greggii & California & Shrubland & 0.1 & acetylene reduction & Kummerow et al. 1978 \\
\hline C. sanguineus & British Columbia & Clearcut & $24-50$ & $\mathrm{~N}$ accretion & Binkley and Husted 1983 \\
\hline C. velutinus & Oregon & Bum /clearcut & $70-108$ & $\mathrm{~N}$ accretion & Youngberg and Wollum 1976 \\
\hline C. velutinus & Oregon & Clearcuts & 101 & acetylene reduction & McNabb and Cromack 1983 \\
\hline C. velutinus & Oregon & Clearcuts & $95-100$ & $\mathrm{~N}$ accretion & Binkley et al. 1982 \\
\hline C. velutinus & Oregon & Clearcuts & $0-20$ & $\mathrm{~N}$ accretion & Zavitkovski and Newton 1968 \\
\hline Cercocarpus ledifolius & California & Open forest & 7 & acetylene reduction & Lepper and Fleschner 1977 \\
\hline Purshia tridentata & Oregon & Open forest & $<1$ & acetylene reduction & Dalton and Zobel 1977 \\
\hline
\end{tabular}



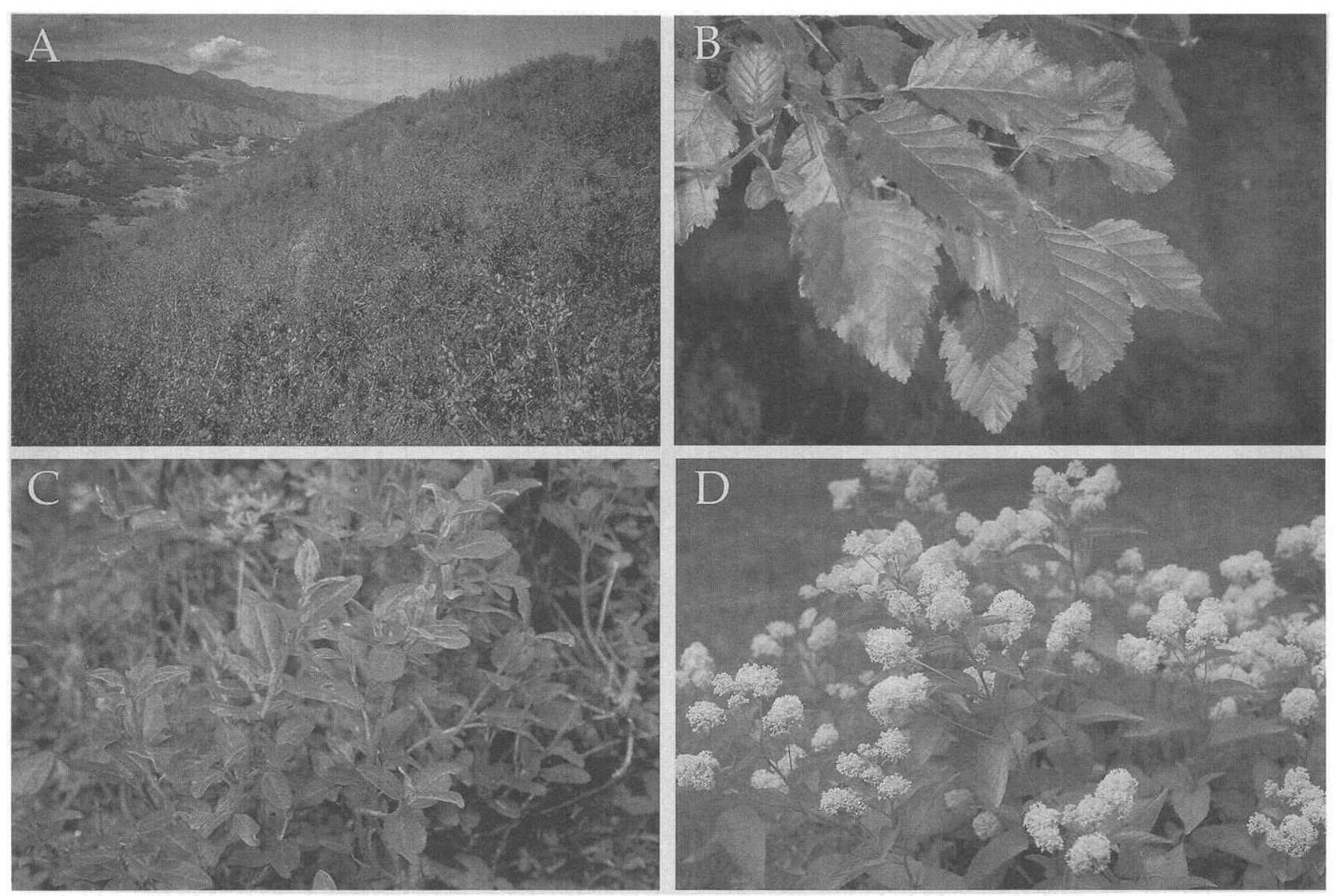

Fig. 2. Some actinorhizal plants characteristic of western U.S. rangelands: A) A stand of mountain mahogany (Cercocarpus montanus Raf.) shrubs in the Front Range of Colorado, B) Thinleaf alder (Alnus incana tenuifolia Nutt.) along a mountain stream in New Mexico, C) Russet buffaloberry (Shepherdia canadensis Nutt.) growing beneath an open pine forest in Wyoming, D) New Jersey tea (Ceanothus americanus L.) from a prairie in Kansas.

reduction, natural isotope $\left({ }^{15} \mathrm{~N}\right)$ techniques, and $\mathrm{N}$ accretion studies (Table 2). For a detailed description of these and other methods see Silvester (1983) or Winship and Tjepkema (1990). There is a great deal of uncertainty in estimating community or ecosystem level inputs of fixed-N using these methods. These uncertainties are especially difficult to address in arid and semiarid systems where the relatively low rates of $\mathrm{N}_{2}$-fixation require greater sensitivity of measurement.

The role of facilitation often attributed to actinorhizal plants during primary succession (Lawrence et al. 1967, Blundon et al. 1993, Chapin et al. 1994) may have as much to do with the addition of organic matter to soils as the direct effects of $\mathrm{N}$ inputs. Crocker and Major (1955) demonstrated that within 50 years of glacial retreat at Glacier Bay, Alaska, thickets of actinorhizal alders had built an organic surface horizon 6-7 cm deep amounting to $5-6 \mathrm{~kg} \mathrm{~m}^{-2}$ of organic matter. Actinorhizal species of Ceanothus and Purshia, which commonly colonize burned areas in western U.S. rangelands (Martin 1983, Conrad et al. 1985), may also provide inputs of soil organic matter. The ecological importance of $\mathrm{N}_{2}$-fixation in these situations may simply be that it enables actinorhizal plants to colonize the site, allowing for their subsequent role in soil organic matter development.

Many actinorhizal plants provide nutritious forage for herbivores because of low foliar C:N ratios, high protein content, and high $\mathrm{N}$ content of dormant tissue (Table 3). Many actinorhizal species have evolved under high levels of herbivory, and for some, growth may be stimulated by browsing (Urness and Jensen 1983, Bilbrough and Richards 1989). Rapid growth of actinorhizal plants following herbivory may be due to the relative availability of fixed- $\mathrm{N}_{2}$ from their Frankia symbionts. This type of response is common in plants provided with high nutrient levels (Maschinski and Whitham 1989).

In western U.S. rangelands, most actinorhizal shrubs are important browse species for big game. Austin and Urness (1983) found the summer diet of mule deer (Odocoileus hemionus) in Utah consisted of $8 \%$ bitterbrush in May and increased steadily to $92 \%$ by September. Woodis (1989) found that over a 2-year period Nevada mule deer's diets consisted of $51 \%$ bitterbrush. Rominger et al. (1988) found 74 to $92 \%$ of the summer diet of bighorn sheep (Ovis canadensis) in the Front Range of Colorado consisted of actinorhizal mountain mahogany leaves. In Idaho, 25 to $85 \%$ of the annual production of actinorhizal redstem ceanothus (Ceanothus sanguineus Pursh.) and 68 to $80 \%$ of snowbrush were utilized by elk (Cervus elaphus) (McCulloch 1955).

Many actinorhizal shrubs are also browsed by livestock (Van Dersal 1938, Hormay 1943, Young and Payne 1948, Furbush 1962, Thilenius and Hungerford 1967, Hickey and Leege 1970, Phillips 1970, Leckenby et al. 1982, Shaw and Monsen 1986). 
Table 3. Nutritional value of some actinorhizal browse species.

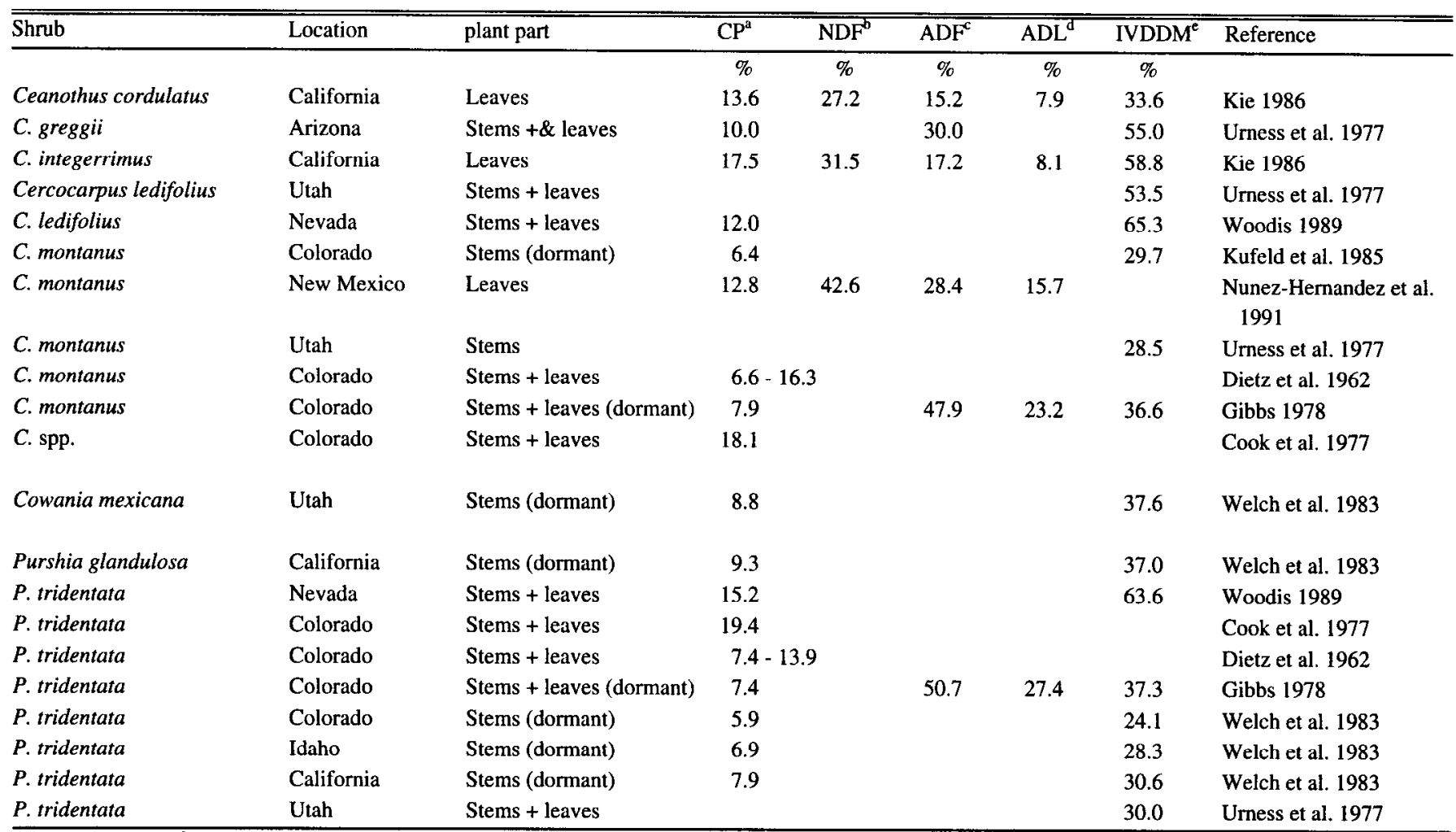

${ }^{a} \mathrm{CP}=$ Crude protein, ${ }^{\mathrm{b}} \mathrm{NDF}=$ Neutral detergent fiber, ${ }^{\mathrm{c}} \mathrm{ADF}=$ Acid detergent fiber, ${ }^{\mathrm{d}} \mathrm{ADL}=$ Acid detergent lignin, ${ }^{\mathrm{e}} \mathrm{IVDDM}=$ In vitro digestible dry matter

Carefully managed livestock grazing may be a valuable tool for stimulating browse production of some actinorhizal shrubs (Garrison 1953, Tueller and Tower 1979, Leckenby et al. 1982, Urness and Jensen 1983, Bilbrough and Richards 1989, Woodis 1989). Hormay (1943) suggests that bitterbrush becomes unpalatable to livestock if it is not grazed moderately each year. Heavy grazing by livestock followed by a rest period may be a useful tool for encouraging regeneration of bitterbrush stands (Phillips 1970). Although grazing can be beneficial for increasing browse production of actinorhizal shrubs, the long-term survival of individual shrubs can be reduced by heavy browsing (McConnell and Smith 1977), especially during the summer (Young and Payne 1948). Frequent light grazing may be detrimental to actinorhizal shrubs in areas where they are a small component of the plant community, as livestock may preferentially browse them (Hormay 1943).

Many small mammals and birds use actinorhizal plants for food and shelter (McAtee 1936, Van Dersal 1938, Evans et al. 1983, Knopf and Olson 1984, Vander Wall 1994). Inputs of $\mathrm{N}$ and organic matter to soils by actinorhizal plants may stimulate soil biological activity (Aplet 1990), which in turn may benefit higher trophic groups. Dawson (1990) suggests that riparian alder trees might be an important source of $\mathrm{N}$ to planktonic organisms at the beginning of food chains in cold infertile streams and montane lakes supporting important trout fisheries. Many actinorhizal species have rich nectaries that attract insects (Hayes 1976, Ferris and Brown 1981) and many ornamental species of Ceanothus can be cultivated in order to attract nectar-feeding butterflies.

\section{Biology of Frankia}

Frankia is a slow-growing filamentous actinomycete that produces 3 cell types: hyphae, vesicles, and spores. Hyphae are vegetative cells that are usually branched and less than $1 \mu \mathrm{m}$ in diameter. The hyphae differentiate to form vesicles and sporangia. Vesicles are terminal swellings on hyphae and are the sites of $\mathbf{N}_{2}$ fixation. Frankia hyphae often produce sporangia which are structures containing numerous spores. The spores are resting structures and probably play an important role in the dormancy and survival of Frankia under adverse conditions (Sussman and Halvorson 1966, Burleigh and Torrey 1990, Burleigh and Dawson 1995). Sporangia can be produced in actinorhizal nodules and in vitro in most Frankia strains, depending on cultural conditions. Sporulation of Frankia in vitro appears to be controlled by temperature, carbon (C) source, and osmotic stress (Tisa et al. 1983, Burleigh and Dawson 1991). Sporulation coincides with the seasonal senescence of vesicles in infected cells of actinorhizal nodules (Becking et al. 1964, Becking 1970, VandenBosch and Torrey 1985). In arid regions sporulation may be triggered by soil drying (Burleigh and Dawson 1991).

Research on Frankia has been hampered due to the difficulty of isolating and culturing Frankia from root nodules. Despite numerous efforts, it was not until 1978 that Frankia was successfully isolated and cultured by Callaham et al. (1978). As a result of these difficulties, a reliable set of criteria for classifying Frankia taxa has not yet been established in the scientific community. Pure cultures of Frankia isolates are often classified based on their host affinities as first defined by Baker (1987), and they are usually given identifying codes based on the plant 
species from which they were isolated (Lechevalier 1983). Lalonde et al. (1988) proposed the assignment of some Frankia strains to 2 species, Frankia alni and Frankia elaeagni, based on genotypic and phenotypic differences (Lalonde et al., 1988). This classification, however, was not widely accepted by Frankia researchers. Recent studies based on DNA relatedness have identified 8 (Nazaret et al. 1991), 9 (Fernandez et al. 1989, Akimov and Dobritsa 1992), and 4 (Normand et al. 1996) genomic groups of Frankia.

About half of the genera, but only a small fraction of actinorhizal species, have had pure cultures of Frankia isolated from their root nodules. Most cultures are from the genera Alnus, Casuarina, Myrica, and Elaeagnus (Lechevalier 1986), and many of these cultures have been isolated from actinorhizal plants growing outside their native range. There is a possibility, therefore, that Frankia cultures may have been identified with host plants that are not of the actinorhizal taxa with which these strains evolved naturally. There are numerous genera of actinorhizal plants from which isolates of symbiotic Frankia have not been obtained, and many Frankia cultures that have been obtained are not capable of reinfecting the host plants from which they were isolated (Lechevalier 1986). Notably missing from culture collections are isolates from Rosaceous and Rhamnaceous actinorhizal shrubs of the western U.S. Until culture collections become more representative of the true diversity of actinorhizal species, it is unlikely that an acceptable taxonomic classification of Frankia will be possible. Current efforts by Philippe Normand in Lyon, France to combine PCR techniques in conjunction with 16S ribosomal RNA sequences derived from Frankia in intact nodules have enabled some taxonomic relationships to be established among isolated and nonisolated Frankia (Normand et al. 1996).

Frankia bacteria are usually found in soils beneath nodulated host plants (Van Dijk 1979, Oremus 1980, Dawson and Klemp 1987, Smolander and Sundman 1987, Arveby and Huss-Danell 1988, Smolander 1990), probably due to the release of Frankia from decaying root nodules (Van Dijk 1984). There are numerous reports of Frankia in soils lacking actinorhizal host plants (Rodriguez-Barrueco 1968, Bermudez de Castro et al. 1976, Van Dijk 1984, Huss-Danell and Frej 1986, Dawson and Klemp 1987, Zitzer et al. 1991, Paschke and Dawson 1992a, 1992b, Paschke et al. 1994), which indicates that Frankia is not an obligate symbiont. Frankia can apparently be spread in the environment via the activity of some bird species (Paschke and Dawson 1993, Burlcigh and Dawson 1995) and other biological vectors (Paschke 1993).

Most actinorhizal plants are usually found to be nodulated in their native habitats. Root nodules can account for a notable portion of belowground biomass in some systems. For instance, McNabb and Kromack (1983) reported $750 \mathrm{~kg} \mathrm{ha}^{-1}$ of nodule biomass for snowbrush growing in western Oregon. There are actinorhizal plant genera, however, that seem to be sparsely nodulated. The most notable of these are bitterbrush and cliffrose that are native to the arid western U.S. (Dalton and Zobel 1977, Nelson 1983, Righetti et al. 1983) and certain species of she-oak (Casuarina spp. and Allocasuarina spp.) which are native to the arid interior of Australia (Lawric 1982). Low lcvels of nodulation in these plants may be due to the low density of infective Frankia in the arid surface soils where these plants grow (Lawrie 1982, Righetti and Munns 1982). Lack of moisture (Righetti et al. 1986,
Dawson et al. 1989), or other factors may limit the growth of free-living saprophytic Frankia in arid regions.

The presence of nodules on host plants is a good indication that Frankia is present in the soil. There is no simple test for determining presence or absence of Frankia in soil that is devoid of host plants. One method to test for Frankia is to grow actinorhizal plants in the test soil and check for nodulation. Quantitative estimates of Frankia-propagule abundance can be made by inoculating host plants with a series of soil dilutions and measuring the relationship between soil quantity and the number of nodules formed (Van Dijk 1984, Paschke 1993). Such tests need to be conducted under aseptic and $\mathrm{N}$-limiting conditions. Another approach is the use of molecular probes to detect Frankia DNA and RNA in situ. Molecular methods have been used to study Frankia ecology in soils (e.g. Hahn et al. 1990b, Myrold and Huss-Danell 1994), but the cost and difficulty of interpreting results may limit widespread use by researchers.

\section{Methodology for Working with Actinorhizal Plants}

Methods for propagating actinorhizal species of western rangelands have been developed for most major taxa (Table 4) while many minor species still await cultivation. Ease of propagation varies considerably within this diverse group of species.

Nursery stock of actinorhizal species often lack root nodules (Danielson and Visser 1990). Seedlings of actinorhizal plants have been experimentally inoculated with Frankia and mycorrhizal fungi prior to planting in order to increase nodulation and mycorrhizal infection (Benoit and Berry 1990, Torrey 1992). This can greatly increase the survivability of planted seedlings. It may also be beneficial, in some cases, to inoculate existing stands of actinorhizal plants with Frankia, although, this has never been attempted on a large scale. As techniques for mass-culturing of Frankia are refined and cultures become more readily available, this might become a possible management tool for stimulating the vigor of actinorhizal shrub stands.

Actinorhizal plants within the families Betulaceae, Myricaceae, and Elaeagnaceae can be readily nodulated by Frankia cultures or nodules from species within the same family (Torrey 1990). A lack of pure cultures of Frankia from other actinorhizal taxa native to western U.S. rangelands, and a lack of knowledge of host-specificity, precludes specific recommendations for optimum plant-Frankia combinations. Most Frankia cultures that are currently available do not effectively nodulate actinorhizal plants in the Rosaceae (Kohls et al. 1994) and Rhamnaceae (Torrey 1990) families. Crushed nodules of these plants offer a viable alternative to pure cultures. Kohls et al. (1994) were able to nodulate several Rosaceous shrubs using crushed nodules of yellow dryad (Dryas drummondii Richards) collected in Alaska.

Common to Frankia-host plant associations is the development of nodules that do not fix $\mathrm{N}_{2}$ (VandenBosch and Torrey 1983, Hahn et al. 1988, Hahn et al. 1990a). These nodules and the Frankia strains that inhabit them are referred to as "ineffective". Ineffective nodules that use carbohydrates from the host plant might actually be pathogenic and demonstrate the fine line between a pathogen and a symbiont. The occurrence of ineffective strains of Frankia and the potential for competitive interactions between ineffective and effective Frankia beneath stands of European black alder (Alnus glutinosa (L.) Gaertn.) has been 
Table 4. A brief guide to the cultivation of common actinorhizal plant species of western U.S. rangelands.

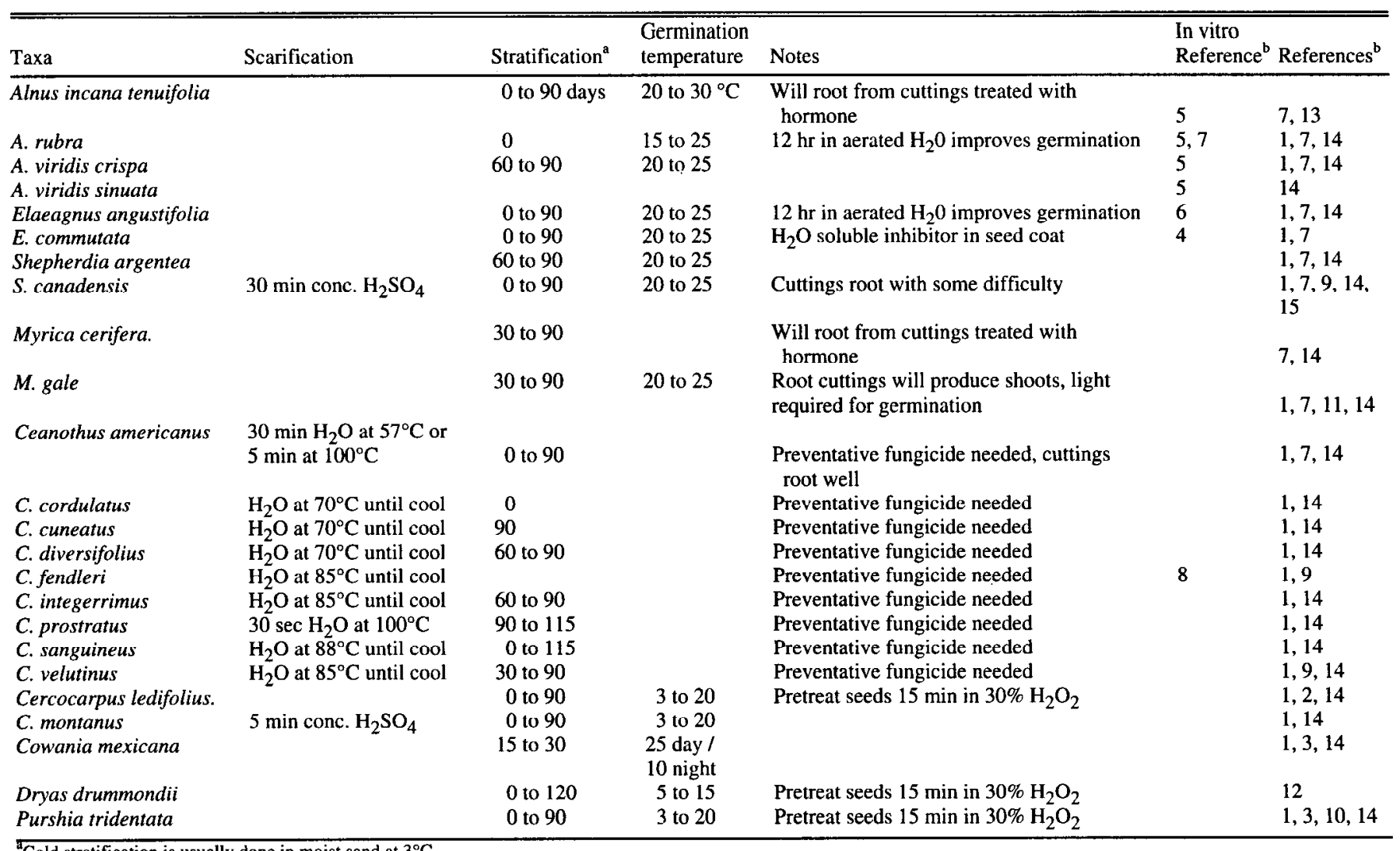

Cold stratification is usually done in moist sand at $3^{\circ} \mathrm{C}$.
${ }^{b}$ References: ${ }^{1}$ USDA For. Serv. $1974,{ }^{2}$ Young et al. $1978,{ }^{3}$ Young and Evans $1981,{ }^{4}$ Fung $1984,{ }^{5}$ Tremblay and Lalonde 1984, ${ }^{6}$ Bertrand and Lalonde $1985,{ }^{7}$ Dirr and Heuser $1987,{ }^{8}$ Borland 1989, ${ }^{9}$ Krishnan 1989, ${ }^{10}$ Meyer and Monsen 1989, ${ }^{11}$ Schwintzer and Ostrofsky 1989, ${ }^{12}$ Benoit and Berry $1990,{ }^{13}$ Java and Everett $1992,{ }^{14}$ Young and Young 1992.

reported by Van Dijk and Sluimer-Stolk (1990). These observations illustrate the danger of introducing Frankia that is not well characterized into western U.S. rangelands without prior considerations of effectivity and competition with native Frankia strains.

At this time, there is no commercially available Frankia inoculum for actinorhizal plants. Several university and government laboratories maintain collections of Frankia cultures for research. For now, nurseries and land managers must rely on field-collected soil or nodules for establishing actinorhizal symbioses. A reliable source of soil or nodules for inoculum is from beneath nodulated actinorhizal plants near the planting site. Methods for inoculating actinorhizal plants with Frankia can be found in Périnet et al. (1985), Benoit and Berry (1990) and Molina et al. (1994).

\section{Future Recommendations}

The study of the actinorhizal symbiosis is in its infancy. Despite the abundance of actinorhizal plants in western U.S. rangelands, this region and its actinorhizal flora are greatly underrepresented in the actinorhizal literature. Many questions need to be addressed. These include: 1) to what extent do actinorhizal shrubs contribute to the $\mathrm{N}$ economy of rangelands? 2) with what types of Frankia do actinorhizal shrubs in the Rosaceae and Rhamnaceae families form a symbiosis? 3) what factors limit nodulation and $\mathrm{N}_{2}$-fixation in actinorhizal rangeland vegetation? 4) can browse productivity be enhanced by large- scale inoculation of rangelands with Frankia? Other areas that need to be addressed are the isolation and culture of Frankia strains from the Rosaceae and Rhamnaceae families, methods for the large-scale production of actinorhizal seedlings and their appropriate Frankia and mycorrhizac symbionts, and the possible transfer of the actinorhizal symbiosis to non-actinorhizal taxa.

Because of their importance in natural ecosystems, actinorhizal plants are slowly gaining recognition as valuable trees and shrubs for diverse uses by humans. Throughout the world, actinorhizal plants are used for reclamation of disturbed soils, windbreaks and soil stabilization, interplanting with food and wood crops, commercial products, and to provide food and cover for wildlife and livestock (Dawson 1986, Bulloch 1987, Baker and Schwintzer 1990, Diem and Dommergues 1990, Wheeler and Miller 1990, Dawson 1992). The actinorhizal species of rangelands in the western U.S. have the potential for similar utility (Table 5). Many of the actinorhizal shrubs in the Rhamnaceae and Rosaceae families are adapted to survive on harsh sites, which makes them ideally suited for reclamation. Species of Elaeagnus, Shepherdia, and Alnus have the potential to add large amounts of fixed $\mathrm{N}$ and $\mathrm{C}$ to soils and they should be given more consideration as soilimprovement tools. The development of sterile cultivars of the weedy exotics Russian- and autumn-olive would allow for their expanded use and would be a major achievement for the reclamation industry.

The Rosaceous actinorhizal plants of the western U.S. perhaps hold great promise for progress in actinorhizal research. It is within this family that numerous non-actinorhizal genera coexist. 
Table 5. Actinorhizal plant species characteristic of western U.S. rangelands and their possible uses.

\begin{tabular}{|c|c|c|c|}
\hline Taxa & Range & Habitat & Uses \\
\hline Alnus rubra & Pacific N.W., N. Idaho & Streambanks, moist slopes and floodplains & $\begin{array}{l}\text { Lumber, soil stabilization, } \\
\text { soil improvement }\end{array}$ \\
\hline A. viridis sinuata & Coastal Alaska to Cascades & $\begin{array}{l}\text { Moist rocky streambanks and slopes, open } \\
\text { woodlands }\end{array}$ & $\begin{array}{l}\text { Soil stabilization, } \\
\text { reclamation }\end{array}$ \\
\hline Elaeagnus commutata & N. Rockies to Minnesota & Dry rocky slopes, rocky stream beds & $\begin{array}{l}\text { Wildlife, reclamation, } \\
\text { ornammental }\end{array}$ \\
\hline Shepherdia canadensis & W. Cascades to Rockies & Open forests, dry rocky slopes & Reclamation, wildlife \\
\hline Myrica spp. & Coastal regions & $\begin{array}{l}\text { Streambanks, lakeshores, moist slopes and } \\
\text { floodplains, coastal bogs }\end{array}$ & $\begin{array}{l}\text { Soil stabilization, wildlife, } \\
\text { reclamation }\end{array}$ \\
\hline Ceanothus cordulatus & S. Oregon to Baja Califomia & Open forests, disturbed sites & Browse \\
\hline C. cuneatus & California to Oregon & Chaparral, open dry forests & Browse \\
\hline C. diversifolius & California & Forest understory & Soil stabilization \\
\hline C. gloriosus & Coastal California & Coastal bluffs & $\begin{array}{l}\text { Ornamental, soil } \\
\text { stabilization }\end{array}$ \\
\hline C. prostratus & Sierra Nevada to S. Cascades & Dry disturbed sites, open forests & $\begin{array}{l}\text { Soil stabilization, } \\
\text { ornamental }\end{array}$ \\
\hline C. sanguineus & Cascades to N. Rockies & Mountain shrublands, forest clearings & Browse, reclamation \\
\hline C. velutinus & Cascades, Sierra Nevada, Rockies & $\begin{array}{l}\text { Forest understories and clearings, disturbed } \\
\text { sites }\end{array}$ & $\begin{array}{l}\text { Reclamation, browse, } \\
\text { ornamental }\end{array}$ \\
\hline Cercocarpus spp. & Western U.S. & $\begin{array}{l}\text { Dry slopes and ridgcs, canyon bottoms, } \\
\text { chaparral foothills }\end{array}$ & $\begin{array}{l}\text { Browsc, rcclamation, soil } \\
\text { stabilization, ornamental }\end{array}$ \\
\hline Cowania spp. & Great Basin to W. Texas & Dry shallow soils & Browse, ornamental \\
\hline Dryas drummondii ${ }^{a}$ & Alaska to S. Rockies & Tundra, alpine and polar rocky terraces & Reclamation \\
\hline Purshia tridentata & W. Cascades to Rockies & Chaparral, dry slopes, open dry forests & $\begin{array}{l}\text { Browse, reclamation, soil } \\
\text { stabilization }\end{array}$ \\
\hline
\end{tabular}

${ }^{2}$ Nodulation status uncertain in alpine habitats of lower 48 states.

Many of these non-actinorhizal genera are closely related to actinorhizal species, which suggests the possibility of future genetic manipulation. Non-nodulating Apache plume (Fallugia paradoxa [D. Don] Endl.), for example, can be grafted onto the nodulated root stock of cliffrose (Kyle et al. 1986). The genetic transfer of nodulating ability has been attempted in non-actinorhizal birch (Betula spp.) trees (a close relative of alders) (Séguin and Lalonde 1990). If successful, genetic transfer of nodulating ability to species of the Rosaceae (e.g. strawberry, cherry, apple, and raspberry), could represent a significant use of gene transfer technology. Before these goals are pursued however, the more immediate task of understanding the basic biology of this symbiosis in rangeland systems is at hand.

\section{Literature Cited}

Akimov, V.N. and S.V. Dobritsa. 1992. Grouping of Frankia strains on the basis of DNA relatedness. System. Appl. Microbiol. 15:372-379.

Aplet, G.H. 1990. Alteration of earthworm community biomass by the alien Myrica faya in Hawai' 'i. Oecologia 82:414-416.

Arnebrant, K., H. Ek, R.D. Finlay, and B. Söderström. 1993. Nitrogen translocation between Alnus glutinosa (L.) Gaertn. seedlings inoculated with Frankia sp. and Pinus contorta Doug. ex Loud seedlings connected by a common ectomycorrhizal mycelium. New Phytol. 124:231-242.

Arveby, A.S. and K. Huss-Danell. 1988. Presence and dispersal of infective Frankia in peat and meadow soils in Sweden. Biol. Fertil. Soils 6:39-44.
Austin, D.D. and P.J. Urness. 1983. Summer use of bitterbrush rangelands by mule deer. p. 203-212. In: A.R. Tiedemann and K.L. Johnson (eds.), Proc. - Research and management of bitterbrush and cliffrose in western North America. USDA Forest Serv., Gen. Tech. Rep. INT-152 Ogden, Ut.

Ba, A.M., B. Sougoufara, and D. Thoen. 1987. The triple symbiosis of Casuarina equisetifolia in Senegal. p.121. In: D.M. Sylvia, L.L. Hung and J.H. Graham (eds.), Mycorrhizae in the next decade: practical applications and research priorities. Inst. Food Agr. Sci., Univ. Florida, Gainesville, Fla.

Baker, D.D. 1987. Relationships among pure and cultured strains of Frankia based on host specificity. Physiol. Plantarum 70:245-248.

Baker, D.D. and C.R. Schwintzer. 1990. Introduction. p. 1-13. In: C.R. Schwintzer and J.D. Tjepkema (eds.), The biology of Frankia and actinorhizal plants. Academic Press, San Diego, Calif.

Barbour, M.G. and J. Major. 1988. Terrestrial vegetation of California. Calif. Native Plant Soc. Spec. Pub. Number 9, Calif. Native Plant Soc., Calif.

Becking, J.H. 1970. Plant-endophyte symbiosis in non-leguminous plants. Plant Soil 32:611-654.

Becking, J.H. 1979. Nitrogen fixation by Rubus ellipticus J.E. Smith. Plant Soil 53:541-554.

Becking, J.H., W.E. deBoer, and A.L. Houwink. 1964. Electron microscopy of the endophyte of Alnus glutinosa. Antionie van Leeuwenhoek 30:343-376.

Benoit, L.F. and A.M. Berry. 1990. Methods for production and use of actinorhizal plants in forestry, low-maintenance landscapes, and revegetation. p. 281-297. In: C.R. Schwintzer and J.D. Tjepkema (eds.), The biology of Frankia and actinorhizal plants. Academic Press, San Diego, Calif.

Benson, D.R. 1988. The genus Frankia: actinomycete symbionts of plants. Microbiological Sci. 5:9-12.

Berliner, R. and J.G. Torrey. 1989. On tripartite Frankia - mycorrhizal associations in the Myricaceae. Can. J. Bot. 67:1708-1712. 
Bermudez de Castro, F., C. Miguel, and C. Rodriguez-Barrueco. 1976. A study of the capacity of soil to induce nodules of Alnus glutinosa (L.) Gaertn. and Myrica gale L. with special reference to the specificity of the endophytes. Ann. Microbiol. (Paris) 127A:307-315.

Bertrand, L.J. and M. Lalonde. 1985. In vitro propagation and nodulation by Frankia of actinorhizal Russian olive (Elaeagnus angustifolia L.). Plant Soil 87:143-152.

Bilbrough, C.J. and J.H. Richards. 1989. Effects of spring growth patterns of sagebrush and bitterbrush following simulated winter browsing. In: Proceedings-dynamics of ecophysiological processes in tree crowns and forest canopies. USDA Forest Serv., NC Forest Range Exp. Sta., Rhinelander, Wisc.

Binkley, D. and L. Husted. 1983. Nitrogen accretion, soil fertility, and Douglas-fir nutrition in association with redstem Ceanothus. Can. J. Forest Res. 13:122-125.

Binkley, D., K. Cromack, Jr., and D.D. Baker. 1994. Nitrogen fixation by red alder: biology, rates, and controls. p. 57-72. In: D.E. Hibbs, D.S DeBell, and R.F. Tarrant (eds.), The biology and management of red alder. Oregon State Univ. Press, Corvallis, Ore.

Binkley, D., K. Cromack, Jr., and R.L. Fredrikson. 1982. Nitrogen accretion and availability in some snowbrush ecosystems. Forest Sci. 28:720-724.

Blundon, D.J., D.A. MacIsaac, and M.R.T. Dale. 1993. Nucleation during primary succession in the Canadian Rockies. Can. J. Bot. 71:1093-1096.

Borland, J. 1989. Cercocarpus ledifolius. Amer. Nurseryman. 170:154.

Bulloch, B.T. 1987. Actinorhizal plants for soil conservation in New Zealand. A review of potential and research. Royal New Zealand Inst. Hort. Annu. J. 14:33-38.

Burleigh, S.H. and J.O. Dawson. 1991. Effects of sodium chloride and melibiose on the in vitro growth and sporulation of Frankia strain HFPCcI3 isolated from Casuarina cunninghamiana. Aust. J. Ecol. 16:531-535

Burleigh, S.H. and J.O. Dawson. 1995. Spores of Frankia strain HFPCcI3 nodulate Casuarina equisetifolia after passage through the digestive tracts of captive parakeets (Melopsittacus undulatus). Can. J. Bot. 73:1527-1530.

Burleigh, S. and J.G. Torrey. 1990. Effectiveness of different Frankia cell types as inocula for the actinorhizal plant Casuarina. Appl. and Environ. Microbiol. 56:2565-2567.

Callaham D., P. Del Tredici, and J.G. Torrey. 1978. Isulation and cultivation in vitro of the actinomycete causing root nodulation in Comptonia. Sci. 199:899-902.

Chapin, F.S., III and R.A. Kedrowski. 1983. Seasonal changes in nitrogen and phosphorus fractions and autumnal retranslocation in evergreen and deciduous taiga trees. Ecol. 64:376-391.

Chapin, F.S., III, L.R. Walker, C.L. Fastie, and L.C. Sharman. 1994 Mechanisms of primary succession following deglaciation at Glacier Bay, Alaska. Ecol. Monograph 64:149-175.

Conrad, S.G., A.E. Jaramillo, K. Cromack, Jr., and K. Sharon. 1985. The role of the genus Ceanothus in western forest ecosystems. USDA. Forest Serv. Gen. Tech. Rep. PNW-182.

Cook, C.W., R.D. Child, and L.L. Larson. 1977. Digestible protein in range forages as an index to nutrient content and animal response. Range Science Dep. Ser. Number 29., Colorado State Univ., Fort Collins, Colo.

Côté, B. and J.O. Dawson. 1986. Autumnal changes in total nitrogen, saltextractable proteins and amino acids in leaves and adjacent bark of black alder, eastern cottonwood and white basswood. Physiologia Plantarum 67:102-108.

Crocker, R.L. and J. Major. 1955. Soil development in relation to vegetation and surface age at Glacier Bay, Alaska. J. Ecol. 43:427-448.

Dalton, D.A. and D.B. Zobel. 1977. Ecological aspects of nitrogen fixation by Purshia tridentata. Plant Soil 48:57-80.

Danielson, R.M. and S. Visser. 1990. The mycorrhizal and nodulation status of container-grown trees and shrubs reared in commercial nurseries. Can. J. Forest Res. 20:609-614.

Dawson, J.O. 1986. Actinorhizal plants: Their use in forestry and agriculture. Outlook on Agr. 15:202-208.

Dawson, J.O. 1990. Interactions among actinorhizal and associated plant species. p. 299-316. In: C.R. Schwintzer and J.D. Tjepkema (eds.), The biology of Frankia and actinorhizal plants. Academic Press, San Diego, Calif

Dawson, J.O. 1992. Nitrogen fixation in forests and agroforestry. p. 227-253. In: F.B. Metting, Jr. (ed.), Soil microbial ecology: Applications in agriculture and environmental management. Marcel Dekker, Inc., N.Y.

Dawson, J.O. and D.T. Funk. 1981. Seasonal change in foliar nitrogen concentration of Alnus glutinosa. Forest Sci. 27:239-243.
Dawson, J.O. and M.T. Klemp. 1987. Variation in the capacity of black alder to nodulate in central Illinois soils, p. 255-260. In: R.L. Hay, F.W. Woods and H. DeSelm (eds.), Sixth central hardwood forest conference. Dep. Forest., Wildl. and Fisheries, Univ. Tennessee, Knoxville, Tenn.

Dawson, J.O., D.G. Kowalski, and P.J. Dart. 1989. Variation with soil depth, topographic position and host species in the capacity of soils from an Australian locale to nodulate Casuarina and Allocasuarina seedlings. Plant Soil 118:1-13.

Diem, H.G. and Y.R. Dommergues. 1990. Current and potential uses and management of Casuarinaceae in the tropics and subtropics. p. 317-342. In: C.R. Schwintzer and J.D. Tjepkema (eds.), The biology of Frankia and actinorhizal plants. Academic Press, San Diego, Calif.

Dietz, D.R., R.H. Udall, and L.E. Yeager. 1962. Chemical composition and digestibility by mule deer of selected forage species, Cache La Poudre Range, Colorado. Tech. Pub. Number 14. Colo. Game and Fish Dep.

Dirr, M.A. and C.W. Heuser Jr. 1987. The reference manual of woody plant propagation: from seed to tissue culture. Varsity Press, Athens, Ga.

Evans, R.A., J.A. Young, G.J. Cluff, and J.K. McAdoo. 1983. Dynamics of antelope bitterbrush seed caches. p. 195-202. In: A.R. Tiedemann and K.L Johnson (eds.). Proceedings-research and management of bitterbrush and cliffrose in western North America. USDA Forest Serv., Gen. Tech. Rep. INT-152. Ogden, Ut.

Fernandez, M.P., H. Meugnier, P.A.D. Grimont, and R. Bardin. 1989. Deoxyribonucleic acid relatedness among members of the genus Frankia. Int. J. Systematic Bacteriology 39:424-429.

Ferris, C.D. and F.M. Brown (eds.). 1981. Butterflies of the Rocky Mountain States. Univ. Okla. Press, Norman, Okla

Findley, J. 1994. Antelope bitterbrush - bluebunch wheatgrass. SRM 104. p. 4-5. In: T.N. Shiflet (ed.), Rangeland cover types of the United States. Society for Range Manage., Denver, Colo.

Fraga-Beddiar, A. and F. Le Tacon. 1990. Interactions between VA mycorrhizal fungus and Frankia associated with alder (Alnus glutinosa [L.] Gaertn.). Symbiosis 9:247-258

Fung, M.Y.P. 1984. Silverberry seed pretreatment and germination techniques. Tree Planters' Notes 35(summer):32-33.

Furbush, P.B. 1962. Feed from brush: an evaluation of some important California browse plants. Calif. Division of Forest. Sacramento, Calif.

Garrison, G.A. 1953. Effects of clipping on some range shrubs. J. Range Manage. 6:309-317.

Gibbs, H.D. 1978. Nutritional quality of mule deer foods, Piceance Basin, Colorado. M.S. Thesis, Colorado State Univ., Fort Collins, Colo.

Hahn, D., M.J.C. Starrenburg, and A.L.D. Akkermans. 1988. Variable compatibility of cloned Alnus glutinosa ecotypes against ineffective Frankia strains. Plant and Soil 107:233-243.

Hahn, D., M.J.C. Starrenburg, and A.L.D. Akkermans. 1990a. Growth increment of Alnus glutinosa upon dual inoculation with effective and ineffective Frankia strains. Plant and Soil 122:121-127.

Hahn, D., R. Kester, M.J.C. Starrenburg, and A.D.L. Akkermans. 1990b. Extraction of ribosomal RNA from soil for detection of Frankia with oligonuceotide probes. Archives of Microbiol. 154:329-335.

Hays, B. 1976. Planting the Elaeagnus Russian and autumn olive for nectar. Amer. Bee J. 116:74-82.

Hendrickson, O.Q. and D. Burgess. 1989. Nitrogen-fixing plants in a cutover lodgepole pine stand of southern British Columbia. Can. J. Forest. Res. 19:936-939.

Hibbs, D.E. and K. Cromack, Jr. 1990. Actinorhizal plants in Pacific Northwest forests. p. 343-363. In: C.R. Schwintzer and J.D. Tjepkma (eds.). The biology of Frankia and actinorhizal plants. Academic Press, San Diego, Calif.

Hickey, W.O. and T.A. Leege. 1970. Ecology and management of redstem ceannthus. A review. Wildl. Bull. Number 4. Idaho Fish and Game Dep., Boise, Ida.

Hitchcock, C.L. and A. Cronquist. 1973. Flora of the Pacific Northwest: an illustrated manual. Univ. Wash. Press, Seatle, Wash.

Hormay, A.L. 1943. Bitterbrush in California. USDA Forest. Serv., Res. Note Number 34. Berkley, Calif.

Huss-Danell, K. and A. Frej. 1986. Distribution of Frankia in soils from forest and afforestation sites in northern Sweden. Plant Soil 90:407-418.

Java, B.J. and R.L. Everett. 1992. Rooting hardwood cuttings of sitka and thinleaf alder. p. 138-141. In: Proceedings-symposium on ecology and management of riparian shrub communities. USDA Forest Serv. Gen. Tech. Rep. INT-289. Ogden, Ut.

Kie, J.G. 1986. Nutritive quality of Ceanothus shrubs in California mixed conifer forest. J. Range Manage. 39:521-526. 
Killingbeck, K.T. 1993. Inefficient nitrogen resorption in genets of the actinorhizal nitrogen fixing shrub Comptonia peregrina: physiological ineptitude or evolutionary tradeoff? Oecologia 94:542-549.

Klemmedson, J.O. 1979. Ecological importance of actinomycete-nodulated plants in the western United States. Botanical Gazette 140(Suppl.):s91-s96.

Knopf, F.L. and T.E. Olson. 1984. Naturalization of Russian-olive: implications to Rocky Mountain wildlife. Wildl. Soc. Bull. 12:289-298.

Kohls, S.J., J. Thimmapuram, C.A. Buschena, M.W. Paschke, and J.O. Dawson. 1994. Nodulation patterns of actinorhizal plants in the family Rosaceae. Plant Soil 162:229-239.

Krishnan, S. 1989. Propagation of native drought tolerant shrubs - Ceanothus spp. and Shepherdia spp. M.S. Thesis, Colorado State Univ., Fort Collins, Colo.

Kufeld, R.C., M.L. Stevens, and D.C. Bowden. 1985. Site variation in forage qualities of mountain mahogany and serviceberry. J. Range Manage. $38: 458-460$.

Kummerow, J., J.V. Alexander, J.W. Neel and K. Fishheck. 1978. Symbiotic nitrogen fixation in Ceanothus roots. Amer. J. Bot. 65:63-69.

Kyle, N.E., J.L. Jakobek, R.A. Backhaus, J.C. Stutz, and T.L. Righetti. 1986. Micrngrafting between $\mathrm{N}$-fixing and non- $\mathrm{N}$-fixing genera of the Rosaceae. Bot. Gaz. 147:243-246.

Lalonde, M., L. Simon, J. Bousquet, and A. Seguin. 1988. Advances in the taxonomy of Frankia: Recognition of species alni and elaeagni and novel subspecies pommerii and vandijkii. p. 671-680. In: H. Bothe, F.J. de Bruijn and W.E. Newton (eds.), Nitrogen fixation: hundred years after. Gustav Fischer, Stuttgart, Germany.

Lawrence, D.B., R.E. Schoenike, A. Quispel, and G. Bond. 1967. The role of Dryas drummondii in vegetation development following ice recession at Glacier Bay, Alaska, with special reference to its nitrogen fixation by root nodules. J. Ecol. 55:793-813.

Lawrie, A.C. 1982. Field nodulation in nine species of Casuarina in Victoria. Australian J. But. 30:447-46.

Lechevalier, M.P. 1983. Cataloging Frankia strains. Can. J. Bot. 61:2964-2967.

Lechevalier, M.P. 1986. Catalog of Frankia strains. Actinomycetes 19:131-162.

Leckenby, D.A., D.P. Sheehy, C.H. Nellis, R.J. Scherzinger, I.D. Luman, W. Elmore, J.C. Lemos, L. Doughty, and C.E. Trainer. 1982. Wildlife habitats in managed rangelands-the Great basin of Southeastern Oregon: Mule deer. USDA Forest Serv. Gen. Tech. Rep. PNW-139, Portland, Ore.

Leege, T.A. 1979. Effects of repeated prescribed burns on Northern Idaho elk browse. Northwest Sci. 53:107-113.

Lepper, M.G. and M. Fleschner. 1977. Nitrogen fixation by Cercocarpus ledifolius (Rosaceae) in pioneer habitats. Oecologia 27:333-338.

Llinares, F., D. Muñoz-Mingarro, N. Acero, and A. Probanza. 1992. Temporal variation of the nitrogen concentration in aerial organs on nitrogen fixing and nonfixing riparian species. Orsis 7:125-130.

Martin, R.E. 1983. Antelope bitterbrush seedling establishment following prescribed burning in the pumice zone of the Southern Cascade Mountains. p. 82-90. In: Proceedings-research and management of bitterbrush and cliffrose in western North America. USDA Forest Serv. Gen. Tech. Rep. INT-152, Ogden, Ut.

Maschinski, J. and T.G. Whitham. 1989. The continuum of plant responses to herbivory: The influence of plant association, nutrient availability, and timing. Amer. Natur. 134:1-19.

McAtee, W.L. 1936. Groups of plants valuable for wildlife utilization and erosion control. USDA Circ. Number 412, Washington, D.C.

MeConnell, B.R. and J.G. Smith. 1977. Influence of grazing on age-yield interactions in bitterbrush. J. Range Manage. 30:91-93.

McCulloch, C.Y., Jr. 1955. Utilization of winter browse on wilderness big game range. J. Wildl. Manage. 19:206-215.

McNabb, D.H. and K. Cromack, Jr. 1983. Dinitrogen fixation by a mature Ceanothus velutinus (Dougl.) stand in the Western Oregon Cascades. Can. J. Microbiol. 29:1014-1021.

Meyer, S.E. and S.B. Monsen. 1989. Seed germination of antelope bitterbrush (Purshia tridentata). p. 147-157. In: Proceedings-symposium on shrub ecophysiology and biotechnology. USDA Forest Serv., Gen. Tech. Rep. INT-256, Ogden, Ut.

Molina, R., D. Myrold, and C.Y. Li. 1994. Root symbioses of red alder: lechnological opportunities for enhanced regeneration and soil improvement. p. 23-46. In: D.E. Hibbs, D.S. DeBell and R.F. Tarrant (eds.), The biology and management of red alder. Ore. State Univ. Press, Corvallis, Ore.
Myrold, D.D. and K. Huss-Danell. 1994. Population dynamics of Alnusinfective Frankia in a forest soil with and without host trees. Soil Biol. Biochem. 26:533-540.

Nazaret, S., B. Cournoyer, P. Normand, and P. Simonet. 1991. Phylogentic relationships among Frankia genomic species determined by use of amplified 16s rDNA sequences. J. Bacteriol. 173:4072-4078.

Nelson, D.L. 1983. Occurrence and nature of actinorhizae on Cowania stansburiana and other Rosaceae. p. 225-239. In: A.R. Tiedemann and K.L. Johnson (eds.), Proceedings - Research and management of bitterbrush and cliffrose in Western North America. USDA Forest Serv., Gen. Tech. Rep. INT-152, Ogden, Ut.

Normand, P., S. Orso, P. Jeannin, C. Chapelon, J. Dawson, L. Evtushenko and A.K. Mirsa. 1996. Molecular phylogeny of the genus Frankia and related genera and emendation of family Frankiaceae. Int. J. Systematic Bacteriology. 46:1-9.

Nunez-Hernandez, G., J.D. Wallace, J.L. Holechek, M.L. Galyean, D.W. King, and R.M. Katting. 1991. Mountain mahogany and cottonseed meal as supplements for grass hay. J. Range Manage. 44:497-500.

Olff, H., J. Huisman, and B.F. Van Tooren. 1993. Species dynamics and nutrient accumulation during early primary succession in coastal sand dunes. J. Ecol. 81:693-706.

Oremus, P.A.I. 1980. Occurrence and infective potential of the endophyte of Hippophae rhamnoides L. ssp. rhamnoides in coastal sand-dune areas. Plant Soil 56:123-139.

Paschke, M.W. 1993. Distribution and dispersal of Frankia. Ph.D. Dissertation, University of Illinois at Urbana-Champaign, Urbana, Ill.

Paschke, M.W. and J.O. Dawson. 1992a. Frankia abundance in soils beneath Betula nigra and other non-actinorhizal woody plants. Acta Occologia 13:407-415.

Paschke, M.W. and J.O. Dawson. 1992b. The occurrence of Frankia in tropical forest soils of Costa Rica. Plant Soil 142:63-67.

Paschke, M.W. and J.O. Dawson. 1993. Avian dispersal of Frankia. Can. J. Bot. 71:1128-1131.

Paschke, M.W., J.O. Dawson, and B.M. Condon. 1994. Frankia in prairie, forest, and cultivated soils of central Illinois, U.S.A. Pedobiologia 38:546-551.

Périnet, P., J.G. Brouillette, J.A. Fortin, and M. Lalonde. 1985. Large scale inoculation of actinorhizal plants with Frankia. Plant Soil 87:175-183.

Phillips, T.A. 1970. The status of antelope bitterbrush in the Cassia Mountain area of Southern Idaho. USDA Forest Serv., Range Improvement Notes 15(4): 1-15, Ogden, Ut.

Righetti, T.L. and D.N. Munns. 1982. Nodulation and nitrogen fixation in Purshia: inoculation responses and species comparisons. Plant Soil 65:383-396.

Righetti, T.L., C.H. Chard, and R.A. Backhaus. 1986. Soil and environmental factors related to nodulation in Cowania and Purshia. Plant Soil 91:147-160.

Righetti, T.L., C.H. Chard, and D.N. Munns. 1983. Opportunities and approaches for enhancing nitrogen fixation in Purshia, Cowania, and Fallugia. p. 214-224. In: A.R. Tiedemann and K.L. Johnson (eds.), Proceedings-research and management of bitterbrush and cliffrose in western North America. USDA Forest Serv., Gen. Tech. Rep. INT-152, Ogden, $\mathrm{Ut}$.

Ritchie, I.C. 1987. Postglacial vegetation of Canada. Cambridge Univ. Press, N.Y.

Rodriguez-Barrueco, C. 1968. The occurrence of the root-nodule endophytes of Alnus glutinosa and Myrica gale in soils. J. Gen. Microbiol. 52:189-194.

Rominger, E.M., A.R. Dale, and J.A. Bailey. 1988. Shrubs in the summer diet of Rocky Mountain bighorn sheep. J. Wildl. Manage. 52:47-50.

Rose, S.L. and C.F. Youngberg. 1981. Tripartite associations in snowbrush (Ceanothus velutinus): effect of vesicular-arbuscular mycorrhizae on growth, nodulation and nitrogen fixation. Can. J. Bot. 59:34-39.

Schwintzer, C.A. and A. Ostrofsky. 1989. Factors affecting germination of Myrica gale seeds. Can. J. Forest Res. 19:1 105-1109.

Schwintzer, C.R. and J.D. Tjepkema (eds.). 1990. The biulogy of Frankia and actinorhizal plants. Academic Press, San Diego, Calif.

Séguin, A. and M. Lalonde. 1990. Micropropagation, tissue culture, and genetic transfornation of actinorhizal plants and Betula. p.215-238. In: C.R. Schwintzer and J.D. Tjepkma (eds.), The biology of Frankia and actinorhizal plants. Academic Press, San Diego, Calif. 
Shaw, N. and S.B. Monsen. 1986. 'Lassen' antelope bitterbrush: a browse plant for game and livestock ranges. Rangelands 8:122-124.

Silvester, W.B. 1983. Analysis of nitrogen fixation. p. 173-212. In: J.C. Gordon and C.T. Wheeler (eds.), Biological nitrogen fixation in forest ecosystems: foundations and applications. Martinus Nijhoff/D.W. Junk, The Hague, The Netherlands.

Smolander, A. 1990. Frankia populations in soils under different tree species-with special emphasis on soils under Betula pendula. Plant Soil 121:1-10.

Smolander, A. and V. Sundman. 1987. Frankia in acid soils of forests devoid of actinorhizal plants. Physiol. Plantarum 70:297-303.

Stephens, H.A. 1973. Woody plants of the North Central Plains. Univ. Press of Kans., Lawrence, Kans.

Stowers, M.D. 1985. Further studies on the nodulating potential of Rubus elipticus by the actinomycete Frankia. p. 702. In: H.J. Evans, P.J. Bottomly and W.E. Newton (eds.), Nitrogen fixation research progress. Martinus Nijhoff/D.W. Junk, The Hague, The Netherlands.

Sussman, A.S. and H.O. Halvorson. 1966. Spores: their dormancy and germination. Harper and Row, N.Y.

Thilenius, J.F. 1990. Woody plant succession on earthquake-uplifted coastal wetlands of the Copper River Delta, Alaska. Forest Ecol. Manage. 33/34:439-462

Thilenius, J.F. and K.E. Hungerford. 1967. Browse use by cattle and deer in Northern Idaho. J. Wildlife Man. 31:141-145.

Tiedemann, A.R. and M.M. Furniss. 1985. Soil and litter nutrient responses to looper defoliation of curlleaf mountain mahogany. Forest Sci. 31:382-388.

Tisa, L.M., M. McBride, and J.C. Ensign. 1983. Studies of growth and

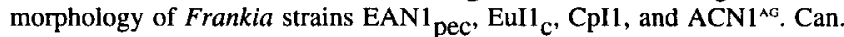
J. Bot. 61:2768-2773.

Torrey, J.G. 1990. Cross-inoculation groups within Frankia and hostendosymbiont associations. p. 83-106. In: C.R. Schwintzer and J.D. Tjepkma (eds.), The biology of Frankia and actinorhizal plants. Academic Press, San Diego, Calif.

Torrey, J.G. 1992. Can plant productivity be increased by inoculation of tree roots with soil microorganisms? Can. J. Forest Res. 22:1815-1823.

Tremblay, F.M. and M. Lalonde. 1984. Requirements for in vitro propagation of seven nitrogen-fixing Alnus species. Plant Cell Tissue Organ Culture 3:189-199.

Tueller, P.T. and J.D. Tower. 1979. Vegetation stagnation in three-phase big game exclosures. J. Range Manage. 32:258-263.

Urness, P.J. and C.H. Jensen. 1983. Goat use in fall increases bitterbrush browse and reduces sagebrush density. p.186-194. In: A.R. Tiedemann and K.L. Johnson (eds.), Proceedings-research and management of bitterbrush and cliffrose in Western North America. USDA Forest Serv., Gen. Tech. Rep. INT-152, Ogden, Ut.

Urness, P.J., A.D. Smith, and R.K. Watkins. 1977. Comparison of in vivo and in vitro dry matter digestibility of mule deer forages. J. Range Manage. 30:119-121

USDA. 1995. The PLANTS database. http://plants.usda.gov/plants. USDA, Natural Resources Conservation Service, National Plant Data Center, Baton Rouge, La.

USDA For. Serv. 1974. Seeds of woody plants in the United States. USDA Agric. Handbook 450, U.S. Government Printing Office, Washington, D.C.

Van Dersal, W.R. 1938. Native woody plants of the United States: Their erosion-control and wildlife values. USDA Misc. Pub. Number 303. Washington, D.C.

Van Dijk, C. 1979. Endophyte distribution in the soil. p.84-94. In: J.C. Gordon, C.T. Wheeler, and D.A. Perry (eds.), Symbiotic nitrogen fixation in the management of temperate forests. Oregon State Univ. Press, Corvallis, Ore.

Van Dijk, C. 1984. Ecological aspects of spore formation in the FrankiaAlnus symbiosis. Ph D. Thesis. University of Leiden, The Netherlands.

Van Dijk, C. and A. Sluimer-Stolk. 1990. An ineffective strain type of Frankia in the soil of natural stands of Alnus glutinosa (L.) Gaertner. Plant and Soil 127:107-121.

VandenBosch, K.A. and J.G. Torrey. 1983. Host-endophyte interactions in effective and ineffective nodules induced by the endophyte of Myrica gale. Can. J. Bot. 61:2898-2902.

VandenBosch, K.A. and J.G. Torrey. 1985. Development of endophytic Frankia sporangia in field- and laboratory-grown nodules of Comptonia perigrina and Myrica gale. Amer. J. Bot. 72:99-108.

Vander Wall, S.B. 1994. Seed fate pathways of antelope bitterbrush: Dispersal by seed-caching yellow pine chipmunks. Ecol. 75:1911-1926.
Vines, R.A. 1960. Trees, shrubs and woody vines of the Southwest. Univ. Tex. Press, Austin, Tex.

Welch, B.L., S.B. Monsen, and N.L. Shaw. 1983. Nutritive value of antelope and desert bitterbrush, Stansbury cliffrose, and Apache-plume. p. 173-185. In: A.R. Tiedemann and K.L. Johnson (eds.), Proceedings-research and management of bitterbrush and cliffrose in western North America. USDA Forest Serv., Gen. Tech. Rep. INT-152, Ogden, Ut.

Wheeler, C.T. and I.M. Miller. 1990. Current and potential uses of actinorhizal plants in Europe. p. 365-389. In: C.R. Schwintzer and J.D. Tjepkema (eds.), The hiolngy of Frankia and actinorhizal plants. Academic Press, San Diego, Calif.

Williams, S.E. 1979. Vesicular-arbuscular mycorrhizae associated with actinomycete-nodulated shrubs, Cercocarpus montanus Raf. and Purshia tridentata (Pursh) DC. Bot. Gaz. 140(Supl.):S115-S119.

Winship, L.J. and J.D. Tjepkema. 1990. Techniques for measuring nitrogenase activity in Frankia and actinorhizal plants. p. 263-280. In: C.R. Schwintzer and J.D. Tjepkma (eds.), The biology of Frankia and actinorhizal plants. Academic Press, San Diego, Calif.

Woodis, S.G. 1989. Dietary relationships of mulc decr and cattle in northwestern Nevada. M.S. Thesis. Colorado State University, Fort Collins, Colo.

Young, J.A. and R.A. Evans. 1981. Germination of seeds of antelope bitterbrush, desert bitterbrush, and cliff rose. USDA, Sci. Education Admin., Agr. Res. Results, AWR-W-17.

Young, J.A. and C.G. Young. 1992. Seeds of woody plants in North America. Dioscorides Press, Portland, Ore.

Young, J.A., R.A. Evans, and D.L. Neal. 1978. Treatment of curlleaf Cercocarpus seeds to enhance germination. J. Wildl. Manage. 42:614-620.

Young, V.A. and G.F. Payne. 1948. Utilization of "key" browse species in relation to proper grazing practices in cutover western white pine lands in northern Idaho. J. Forestry 46:35-40.

Youngberg, C.T. and A.G. Wollum. 1976. Nitrogen accretion in developing Ceanothus velutinus stands. Soil Science Soc. Amer. J. 40:109-112.

Zavitkovski, J. and M. Newton. 1968. Ecological importance of snowbrush, Ceanothus velutinus, in the Oregon Cascades. Ecology 49:1134-1145.

Zitzer, S.F., S.R. Archer, and T.W. Boutton. 1991. Infective capacity of symbiotic nitrogen-fixing bacteria in southern Texas savannas. Bull.(Suppl.) Ecol. Soc. Amer. 72:299. 